\title{
Effect of plant extracts and a disinfectant on biological parameters and pathogenicity of the fungus Beauveria bassiana (Bals.) Vuill. (Ascomycota: Cordycipitaceae)
}

\author{
C. C. Martins ${ }^{a, b}$, L. F. A. Alves ${ }^{b *}$ and A. P. Mamprim ${ }^{b}$ \\ aPrograma de Pós-graduação em Conservação e Manejo de Recursos Naturais, Universidade Estadual do Oeste do \\ Paraná - UNIOESTE, Rua Universitária, 2069, CEP 85819-110, Cascavel, PR, Brasil \\ 'Laboratório de Biotecnologia Agrícola, Universidade Estadual do Oeste do Paraná - UNIOESTE, \\ Rua Universitária, 2069, CEP 85819-110, Cascavel, PR, Brasil \\ *e-mail: luis.alves@unioeste.br
}

Received: September 3, 2014 - Accepted: March 24, 2015 - Distributed: May 31, 2016

\begin{abstract}
The fungus Beauveria bassiana is naturally found in poultry houses and causes high rates of mortality in Alphitobius diaperinus. Laboratory and field experiments have shown the potential of this fungus as an insect control agent. However, in poultry houses, bacteria as Salmonella, can be found and have been studied alternative control methods for this pathogen. Thus, this study aimed to evaluate the effect of plant extracts and a disinfectant on the fungus Beauveria bassiana (strain Unioeste 4). Conidial viability, colony-forming unit (CFU) counts, vegetative growth, conidia production, insecticidal activity of the fungus and compatibility were used as parameters in the evaluation of the effect of these products on the fungus. Alcoholic and aqueous extracts of jabuticaba (Myrciaria cauliflora (Mart.), guava (Psidium guajava (L.)), and jambolan (Syzygium cumini (L.), at concentrations of $10 \%$ as well as the commercial disinfectant, Peroxitane $^{\circledR} 1512 \mathrm{AL}$, were evaluated at the recommended concentrations (RC), 1:200 (RC), $0.5 \mathrm{RC}$ and 2 RC. There was a negative influence of alcoholic and aqueous extracts of jabuticaba, guava and three dilutions of Peroxitane on the viability of conidia. The CFUs and vegetative growth of the fungus were affected only by the Peroxitane (all dilutions). For conidial production, the aqueous extract of guava had a positive effect, increasing production, while the Peroxitane at the $\mathrm{R}$ and $\mathrm{RC}$ concentrations resulted in a negative influence. The mortality of $A$. diaperinus, caused by the fungus after exposure to these products, was $60 \%$ for the peracetic acid at $0.5 \mathrm{RC}$, and above $80 \%$ for the extracts. Thus, the results showed that all the extracts and Peroxitane at RC 0.5 are compatible with the fungus B. bassiana Unioeste 4, however only the extracts had a low impact on inoculum potential.
\end{abstract}

Keywords: Myrciaria cauliflora (Mart.), Psidium guajava (L.), Syzygium cumini (L.), compatibility.

\section{Ação de extratos vegetais e desinfetantes sobre parâmetros biológicos e patogenicidade do fungo Beauveria bassiana (Bals.) Vuill. (Ascomycota: Cordycipitaceae)}

\begin{abstract}
Resumo
O fungo Beauveria bassiana é encontrado naturalmente em aviários de frango de corte, tendo sua eficácia como agente controlador do Alphitobius diaperinus, em condições de laboratório e campo. No entanto, nos aviários encontram-se também bactérias, como a Salmonella, para a qual vêm sendo pesquisadas alternativas de controle. Sendo assim, o objetivo do trabalho foi avaliar o efeito de extratos vegetais e um desinfetante com potencial de uso contra Salmonella spp., sobre os parâmetros biológicos do fungo B. bassiana isolado Unioeste 4. Foram avaliados extratos alcoólicos e aquosos de folhas de jabuticabeira (Myrciaria cauliflora (Mart.)), goiabeira (Psidium guajava (L.)), jamboleiro (Syzygium cumini (L.)), na concentração de $10 \%$ e também o desinfetante comercial Peroxitane ${ }^{\circledR} 1512$ AL na concentração recomendada - 1:200 (CR), 0,5 CR e 2CR. Foram avaliados a: germinação dos conídios, unidades formadoras de colônias (UFC), crescimento vegetativo, produção de conídios e efeito sobre a atividade inseticida do fungo contra adultos de A. diaperinus, bem como a compatibilidade entre produtos e o fungo. Verificou-se influência negativa dos extratos alcoólico e aquoso de jabuticabeira, goiabeira e das três diluições de Peroxitane sobre a viabilidade dos conídios. Já, a UFC e o crescimento vegetativo foram afetados apenas com Peroxitane (em todas as diluições). Para produção de conídios, o extrato aquoso de goiabeira teve efeito positivo, elevando a produção, enquanto as diluições recomendada e o dobro de Peroxitane mostraram influência negativa. Observou-se ainda que a mortalidade de $A$. diaperinus causada pelo fungo após a exposição aos produtos foi de $60 \%$ para o ácido peracético na $0,5 \mathrm{CR}$, já para os extratos foi acima de $80 \%$. Assim, os resultados demonstraram que todos os extratos e o Peroxitane na 0,5 CR são compatíveis com o fungo $B$. bassiana Unioeste 4, porém apenas os extratos tiveram baixo impacto sobre o potencial de inóculo do fungo.
\end{abstract}

Palavras-chave: Myrciaria cauliflora (Mart.), Psidium guajava (L.), Syzygium cumini (L.), compatibilidade. 


\section{Introduction}

In 2012, Brazil produced more than 12 million tons of chicken meat, and exported approximately 4 million tons, being the world's largest exporter of this product (UBABEF, 2013).

Increasing in production has been possible due to the modification of the environment, making it favorable to poultry production, but these modifications also favor pests and diseases associated with poultry, as the lesser meal worm (LMW), Alphitobius diaperinus (Panzer, 1997) (Coleoptera: Tenebrionidae) (O'Connor, 1987). The large population of the LMW found in the poultries aviaries and natural poultry behavior lead the birds to feed on these insects and instead the chicken food, resulting in reduced development, weight loss and increased time to slaughter. It has been emphasized that LMW may play a potential role as vectors of bacteria, especially Salmonella spp. (Lign.), Campylobacter jejuni (Jones) and Escherichia coli (Theod.), bacteria that cause diseases in both poultry and humans (Despins and Axtell, 1995; Hazeleger et al., 2008; Chernaki-Leffer et al., 2010).

Poultry house's environment associated with the presence of the LMW, make aviaries an extremely favorable site for the presence and development of bacteria, which may be transmitted to humans through meat consumption and affect the meat commercialization and limit the exportation (Chernaki-Leffer et al., 2010; Oliveira et al., 2014).

Thus, in order to meet the increased demand for chicken meat and maintain quality, measures are necessary to prevent and control insects and pathogens found in poultry houses. Currently, the most common way to LMW control are chemical insecticides, which, although immediately effective, have a low persistence, require constant reapplications that are stress poultry, may leave residues in meat, selecting insect resistant populations and eliminate natural enemies (Chernaki-Leffer et al., 2011).

Beauveria bassiana (Bals) naturally occurs in poultry houses, causing high rates of mortality of LMW (Alves et al., 2005), and laboratory studies have indicated the potential of this fungus as a control agent of the LMW (Chernaki-Leffer, 2004; Rohde et al., 2006).

Bacteria control can be carried out preventively, with the use of disinfectants derived from ammonia, on poultry house surfaces before installing poultry (Bermudez and Stewart-Brown, 2003). Bacterial control can also be carried out curatively, incorporating antibiotics into feed. It is noteworthy that antibiotics used for birds have the same active ingredients of some formulations used for humans and may cause selection for antimicrobial resistance (Padilha, 2004; Górniak and Spinosa, 2007).

As alternatives for the control of pathogens in poultry, products of vegetable origin or based on organic acids have been shown to be effective under laboratory (Fruet, 2010; Jaenisch et al., 2010; De Bona, 2012) and the use of this control strategy is potentially safer for the environment and less impactful to the conservation of natural enemies of insects and mites, including entomopathogenic fungi.
Thus, the present study aimed to assess the effect of plant extracts and a commercial disinfectant (based on an active organic acid) previously evaluated against some Salmonella spp. serovars on some biological parameters of the fungus $B$. bassiana.

\section{Material and Methods}

\subsection{Product and extracts used}

Aqueous and alcoholic extracts of leaves from plants of jabuticaba (Myrciaria cauliflora (Mart.)), guava (Psidium guajava (L.)), and jambolan (Syzygium cumini (L.)), all of the family Myrtaceae, were used at a $10 \%$ concentration, according to the previous studies of Fruet (2010) and De Bona (2012), which showed inhibitory action on various serovars of Salmonella spp. The commercial disinfectant Peroxitane ${ }^{\circledR} 1512$ AL (peracetic acid, hydrogen peroxide, acetic acid, and stabilizers) at the concentrations of 1:200 (recommended concentration - RC), 2RC and 0.5 RC were assessed. The extracts were prepared according to the methods of De Bona (2012) and Mamprim et al. (2013) to collect, dry, ground and storage of leaves.

To obtain the alcoholic extract, $50 \mathrm{~g}$ of leaves powder was added to $500 \mathrm{~mL}$ ethyl alcohol PA. After 10 days, filtering was performed on sterile filter paper, and the filtrate was rotoevaporated. Following this distilled water was added in a waste weight/volume ratio to obtain a $10 \%$ concentration. Subsequently, vacuum sterilization was performed with a $0.45 \mathrm{~mm}$ pore membrane and the material was stored at $-10{ }^{\circ} \mathrm{C}$ (Mamprim et al., 2013).

To obtain the aqueous extract, $10 \mathrm{~g}$ leaves powder were added to $90 \mathrm{~mL}$ distilled water in a dark glass flask and left for 48 hours at room temperature and protected from light. After this period, filtering was performed in sterile cotton gauze and filter paper, and then the filtrate liquid was maintained at $-10^{\circ} \mathrm{C}$ (Mamprim et al., 2013).

For use in the experiment, extracts were filtered through a membrane with $0.22 \mathrm{~mm}$ porosity. The experiments were conducted with dilutions of $10 \%$ concentration, this being a limit from an economic standpoint. The commercial product was diluted as described above.

\subsection{Microorganism used}

B. bassiana Unioeste 4 strain from the collection of Laboratory of Agricultural Biotechnology Unioeste was used because it presents a high virulence against LMW larvae and adults (Rohde et al., 2006). The fungus was produced in conidia production (CP) culture media (Alves et al., 1998b). For bioassays, a suspension was prepared at $1 \times 10^{9} \mathrm{conidia} / \mathrm{mL}$ in distilled water + Tween $80(0.01 \%)$.

\subsection{Assessment of biological parameters}

B. bassiana biological parameters were assessed according to studies conducted by Silva et al. (2005), Rohde et al. (2006), Oliveira (2009), Mamprim et al. (2013).

A) Germination: Potato Dextrose Agar (PDA) culture media was poured into a Rodac plate. After solidification, $300 \mu \mathrm{L}$ of the conidial suspension 
$\left(1 \times 10^{6}\right.$ conidia $\left./ \mathrm{mL}\right)$ was inoculated in the center of the plates, which were lightly stirred by hand to spread the suspension. Then, the spraying of $250 \mu \mathrm{L}$ of the different treatments solution were sprayed on culture media surface with a Sagima SW775 airbrush spray apparatus at a constant pressure $\left(0.7 \mathrm{kcf} / \mathrm{cm}^{2}\right)$. Plates were held for $16 \mathrm{~h}$ at $26 \pm 1{ }^{\circ} \mathrm{C}$ and12 hour photophase. After that, the number of germinated and non-germinated conidia was counted under an optical microscope $(100 \times)$.

B) Colony Forming Units (CFU): Aliquots of conidia suspension $\left(1 \times 10^{3}\right.$ conidia $\left./ \mathrm{mL}\right)$ were inoculated on PDA culture medium in Petri dishes with a Drigalski loop. Extracts and products were immediately applied as previously described, and then plates were held for five days incubation $\left(26 \pm 1{ }^{\circ} \mathrm{C} ; 12\right.$ hour photoperiod), after which the colonies were counted.

C) Vegetative growth: The fungus was inoculated with a platinum wire loop at three points on the surface of PDA culture media in Petri dishes which were incubated under the same conditions for 48 hours. Then, the spraying of the product and extracts was performed. Plates were again incubated under the same conditions for 7 days. Two perpendicular measurements of the colonies were taken to obtain their mean diameter.

D) Conidia Production: After evaluation of vegetative growth, two colonies from each plate were cut and individually transferred to sterile glass tubes where $10 \mathrm{~mL}$ distilled water with $0.01 \%$ Tween 80 was added for stirring until conidia detachment. After serial dilutions, conidia counts were performed in a Neubauer chamber.

For the control, dishes containing the fungus were sprayed with only sterilized distilled water + Tween $^{\circledR}$ $80(0.01 \%)$. For all treatments and control, four plates were prepared, and each of these plates was considered a replication.

The compatibility between the treatments and the fungus was observed according to the calculation of toxicity proposed by Rossi-Zalaf et al. (2008) (Equation 1).

$\mathrm{IB}=\frac{47[\mathrm{CV}]+43[\mathrm{ESP}]+10[\mathrm{GER}]}{100}$

where:

$\mathrm{IB}=$ Biological index; $\mathrm{CV}($ colony diameter $)=$ percentage of colony vegetative growth after 7 days, compared with the control; ESP (conidia production) = percentage of sporulation of colonies after 7 days, compared with the control; and GER (viability) = percentage of conidia germination after $16 \mathrm{~h}$. The values of CV, ESP and GER were first corrected in relation to their respective controls. The proposed classification for the compatibility of the disinfectant and extracts was performed according to the methods of Rossi-Zalaf et al. (2008).
E) Insecticidal activity: The fungus was inoculated on PDA culture media in Petri dishes. Plates were incubated at $26 \pm 1{ }^{\circ} \mathrm{C}$ with a 12 hour photophase for 48 hours. So, extracts and the peracetic acid at $0.5 \mathrm{CR}$ were sprayed on these plates whose were then incubated for more 7 days at same conditions. Then, the conidia were collected by scraping the surface of the culture medium, transferred to glass tubes and suspensions prepared for application to the LMW according to the Rohde et al. (2006).

\subsection{Statistical analysis}

Data (biological parameters, nutritional influence of the extracts on the conidia production and pathogenicity) were submitted to normality test by Shapiro-Wilk and analyzed by one-way ANOVA and means were compared by Scott-Knott test $(\mathrm{P}<0.05)$, using the statistical program Sisvar (FERREIRA, 2011).

\section{Results and Discussion}

Alcoholic extracts: Only there was a significant reduction in conidia viability with the use of the jabuticaba and guava plants extracts (Table 1).

Other studies have shown that the hydroalcoholic extract of the jabuticaba plant (M. cauliflora) has significant antimicrobial activity against the bacteria Streptococcus spp. (Ros.) and the fungus Candida albicans (Ber.) (Macedo-Costa et al., 2009; Diniz et al., 2010), not being found studies with other microorganisms taxonomically closer to the fungus studied here.

A study on the alcoholic extract of $P$. guajava (guava) at concentrations of $6.5,12.5,25$ and $50 \%$ also demonstrated the inhibitory activity of mycelial growth of Colletotrichum gloeosporoides (Penz.). Although obtained with a fungus of another order, resembles those found in this study regarding the inhibitory action of P. guajava (Boneet et al., 2012).

The extract of the jambolan plant (S. cumini) was the only one that showed no significant inhibitory activity on any of the parameters evaluated. Likewise, Cock (2012) also showed that methanol extracts of Syzygium australe (Ber) and S. luehmannii (F. Muell) had little fungicidal activity against Aspergillus niger (Tiegh). Although the study used extracts from different species, it is likely that classes of phytochemicals produced by these plants are close because they belong to the same genus (Rodrigues et al., 2010).

The classes of compounds present in the alcoholic extract of $S$. cumini are generally similar to those extracted from M. cauliflora and P. guajava and include tannins, flavonoids, anthocyanins alkaloids and others, which have known antibacterial activity (Loguercio et al., 2005; Vargas-Alvarez et al., 2006; De Bona, 2012). The differences in the inhibition of fungus viability may be related to the concentration and diversity of phytochemicals extracted.

Despite viability being a parameter present in the calculation of the biological index, its weight in the 
Table 1. Effects of different alcoholic and aqueous extracts and a disinfectant on conidial viability, colony-forming units (CFU), colony diameter, conidia production and compatibility with the Beauveria bassiana isolate Unioeste 04 under laboratory conditions $\left(26^{\circ} \mathrm{C}\right.$ and $12 \mathrm{~h}$ photoperiod).

\begin{tabular}{|c|c|c|c|c|c|}
\hline Alcoholic extracts & Viability (\%) & CFU & Diameter (cm) & $\begin{array}{c}\text { Conidia Prod. } \\
\left(\times 10^{6} / \mathrm{mL}\right)\end{array}$ & I.B. \\
\hline Control & $98.4 \pm 0.30 \mathrm{a}$ & $113.6 \pm 9.00 \mathrm{a}$ & $2.8 \pm 0.03 \mathrm{a}$ & $49.8 \pm 6.15 a$ & - \\
\hline Guava plant & $95.5 \pm 0.36 b$ & $112.0 \pm 10.80 \mathrm{a}$ & $2.8 \pm 0.02 \mathrm{a}$ & $48.8 \pm 4.97 \mathrm{a}$ & $103.5 \mathrm{C}$ \\
\hline Jabuticaba plant & $94.2 \pm 0.81 b$ & $133.2 \pm 7.78 \mathrm{a}$ & $2.7 \pm 0.03 \mathrm{a}$ & $55.8 \pm 4.39 \mathrm{a}$ & $104.0 \mathrm{C}$ \\
\hline Jambolan plant & $98.3 \pm 1.36 \mathrm{a}$ & $144.4 \pm 12.79 \mathrm{a}$ & $2.8 \pm 0.04 a$ & $57.4 \pm 1.97 \mathrm{a}$ & $107.0 \mathrm{C}$ \\
\hline F test & 6.3 & 2.3 & 0.6 & 0.6 & - \\
\hline C.V. & 1.9 & 18.3 & 2.9 & 22.0 & - \\
\hline Aqueous extracts & Viability (\%) & CFU & Diameter (cm) & $\begin{array}{c}\text { Conidia Prod. } \\
\left(\times 10^{6} / \mathrm{mL}\right)\end{array}$ & I.B. \\
\hline Control & $98.4 \pm 0.30 \mathrm{a}$ & $113.6 \pm 9.00 \mathrm{a}$ & $2.8 \pm 0.03 a$ & $49.8 \pm 6.15 b$ & - \\
\hline Guava plant & $95.8 \pm 0.64 b$ & $140.8 \pm 8.03 \mathrm{a}$ & $2.8 \pm 0.03 \mathrm{a}$ & $65.4 \pm 4.07 \mathrm{a}$ & $113.5 \mathrm{C}$ \\
\hline Jabuticaba plant & $94.6 \pm 0.50 b$ & $126.4 \pm 11.90 \mathrm{a}$ & $2.8 \pm 0.03 a$ & $39.2 \pm 6.98 b$ & $90.8 \mathrm{C}$ \\
\hline Jambolan plant & $99.2 \pm 0.46 \mathrm{a}$ & $125.8 \pm 13.24 \mathrm{a}$ & $2.8 \pm 0.04 a$ & $40.2 \pm 5.18 b$ & $91.7 \mathrm{C}$ \\
\hline F test & 18.4 & 1.0 & 0.8 & 4.4 & - \\
\hline C.V. & 1.1 & 19.0 & 2.9 & 26.1 & - \\
\hline Commercial product & Viability (\%) & CFU & Diameter (cm) & $\begin{array}{l}\text { Conidia Prod. } \\
\left(\times 10^{6} / \mathrm{mL}\right)\end{array}$ & I.B. \\
\hline Control & $98.4 \pm 0.30 \mathrm{a}$ & $113.6 \pm 9.00 \mathrm{a}$ & $2.8 \pm 0.03 a$ & $49.8 \pm 6.15 \mathrm{a}$ & - \\
\hline peracetic acid $0.5 \mathrm{CR}$ & $0.0 \pm 0.00 \mathrm{~b}$ & $0.0 \pm 0.00 \mathrm{~b}$ & $2.4 \pm 0.004 b$ & $50.2 \pm 7.77 \mathrm{a}$ & $84.3 \mathrm{C}$ \\
\hline peracetic acid CR & $0.0 \pm 0.00 \mathrm{~b}$ & $0.0 \pm 0.00 \mathrm{~b}$ & $2.0 \pm 0.03 c$ & $10.7 \pm 0.96 b$ & 42.6 MT \\
\hline peracetic acid $2 \mathrm{CR}$ & $0.0 \pm 0.00 \mathrm{~b}$ & $0.0 \pm 0.00 \mathrm{~b}$ & $1.3 \pm 0.23 \mathrm{~d}$ & $9.0 \pm 1.08 b$ & $34.4 \mathrm{~T}$ \\
\hline F test & 83337.6 & 155.5 & 27.6 & 21.7 & - \\
\hline C.V. $(\%)$ & 1.5 & 35.8 & 12.3 & 37.1 & - \\
\hline
\end{tabular}

Means ( \pm SEM) followed by the same letter in column (within each type of extract) do not differ by the Scott-Knott test at $5 \%$ significance. $0.5 \mathrm{CR}=$ Half the recommended concentration; $\mathrm{CR}=$ Recommended Concentration; $2 \mathrm{CR}=$ Twice the recommended concentration. C.V. $=$ Coefficient of variation. I.B. between 0 and $41=$ toxic $(\mathrm{T})$; between 42 and $66=$ Moderately Toxic (MT); greater than $66=$ compatible (C) Rossi-Zalaf et al. (2008).

calculation is very small (only $10 \%$ ), justifying the result of compatibility.

Aqueous extracts: As observed for the alcoholic extracts, the viability was not affected by the jambolan extract; however, extracts of guava and jabuticaba showed statistically influences.

For CFU counts and colony diameter, there was no interaction of extracts. However, the presence of guava extract in the culture medium significantly stimulated conidia production. Despite all of these plants being in the Myrtaceae family, the variation in results may be directly linked to the nutritional status of the plant, as suggested by Mamprim et al. (2013).

This variation in the interaction of products and biological parameters of $B$. bassiana has also been observed for extracts of eucalyptus (Eucalyptus citriodora (Hook)), chinaberry (Melia azedarach (Lin)) and laurel (Laurus nobilis (Lin)), which affected not only the viability and CFU but also significantly increased conidia production (Mamprim et al., 2013).

Increased conidia production in the presence of the aqueous extract of guava may have two distinct explanations. Studies have demonstrated that conidia production can be increased by increasing the nutrient richness, the amount of carbon and nitrogen compounds in culture medium, or specific carbohydrates in the culture medium (Rombach, 1989; Leite et al., 2003). To corroborate this hypothesis, Mellinger (2006) and Scoparo (2011) found polysaccharides in leaves extracts from Phyllanthus niruri (Lin) and Camellia sinensis (Lin).

Moreover, Moino-Junior and Alves (1998) suggest that fungi, when affected by certain substances, initiate a mechanism of physiological resistance and begin to metabolize compounds that can be used as nutrients, or when suffering from the toxic influence of the medium, initiate a physiological process that increases the production of conidia in a reproductive effort because conidia are considered resistant to adverse conditions. The latter seems quite consistent with the results in our study because the production of conidia was the most affected parameter in the guava extract treatment, and if the change was a result of the addition of nutrients to the medium, most likely other parameters would also be positively influenced.

Despite some parameters being negatively influenced, the Biological Index (Rossi-Zalaf et al., 2008) showed that all aqueous extracts were compatible with the fungus B. bassiana Unioeste 4 (Table 1). 
Peracetic Acid: A negative action of the disinfectant was more significant in total reduction of conidia germination and formation of CFU (Table 1). The difference in diameter of colonies between treatments with peracetic acid and the control (in percentage decline) was not as drastic compared with the other parameters. For conidia production, the product at $0.5 \mathrm{RC}$ did not differ from the control (Table 1).

According to Grezzi (2008), most chemicals disinfectants are used to control, prevent the growth or destroy microorganisms but are not necessarily effective against some resistant forms, such as spores. Both peracetic acid and hydrogen peroxide, which are the main components of the disinfectant formulation, have oxidizing action, cause protein denaturation and rupture of cell membranes.

It is worth noting that exposure time, temperature and concentration are key factors for the inactivation of microorganisms. Thus, more sensitive microorganisms are inactivated in 5 minutes at a concentration of $100 \mathrm{ppm}$ of some compounds, whereas 500-10000 ppm are necessary for removal of spores, with exposure time of 15 seconds to 30 minutes (Rutala, 1997). This explains the production of conidia in colonies with the $0.5 \mathrm{RC}$ treatment because at this concentration the amount of peracetic acid were $2500 \mathrm{ppm}$ (which is in 500-10000 ppm range). Additionally, the disinfectant was applied 48 hours after fungus inoculation and this period of time may have been sufficient for germination and early fungus development.

Different sensitivity levels of microorganisms to products are related to the concentration and to the substance: activity can change from inhibitory to a biocide with increasing concentration in the medium (Ostrosky et al., 2008). This may explain the effect of the gradual increase in concentrations, the product changed from non-toxic (half the recommended dose $(0.5 \mathrm{RC})$ to moderately toxic (recommended dose (CR)) and reaching toxic at twice the recommended concentration (RC 2).

For the parameters of viability and $\mathrm{CFU}$, values equal to zero were observed, and the interaction of compatibility was determined only by the colony diameter (vegetative growth) and conidia production; this explains why the disinfectant at $0.5 \mathrm{RC}$ and $\mathrm{RC}$ resulted in a compatible and moderately toxic classifications, respectively.

Insecticidal activity: In all treatments associated with extracts, there was a high insect mortality caused by the fungus. The opposite was observed in the treatment with peracetic acid, which caused a reduction in fungal efficiency for insect control at RC 0.5 and totally affected fungal activity at $\mathrm{RC}$ and $2 \mathrm{RC}$ (Table 2 ).

Mortality observed in this study for the control (88.6\% in pure fungus) is very close to Rohde et al. (2006). In isolates selection to $A$. diaperinus obtained $86.7 \%$ to adults in the concentration of $1 \times 10^{9}$ conidia/mL by the same fungus $B$. bassiana Unioeste 4.
Table 2. Effects of different alcoholic and aqueous extracts and a disinfectant on insecticidal activity of the Beauveria bassiana isolate Unioeste 04 on Alphitobius diaperinus adults under laboratory conditions $\left(26{ }^{\circ} \mathrm{C}\right.$ and $12 \mathrm{~h}$ photoperiod).

\begin{tabular}{lc}
\hline \multicolumn{1}{c}{ Treatments } & $\begin{array}{c}\text { Mortality caused by } \\
\text { fungus (\%) }\end{array}$ \\
\hline peracetic acid 0.5 CR & $60.0 \pm 3.85 \mathrm{c}$ \\
peracetic acid CR & - \\
peracetic acid 2 CR & - \\
alcoholic extract of guava & $80.0 \pm 3.85 \mathrm{~b}$ \\
alcoholic extract of jabuticaba & $82.2 \pm 5.88 \mathrm{~b}$ \\
alcoholic extract of jambolan & $82.2 \pm 5.88 \mathrm{~b}$ \\
aqueous extract of guava & $97.7 \pm 2.22 \mathrm{a}$ \\
aqueous extract of jabuticaba & $88.8 \pm 2.22 \mathrm{a}$ \\
aqueous extract of jambolan & $91.0 \pm 2.22 \mathrm{a}$ \\
Unioeste 4 (no products) & $88.6 \pm 5.88 \mathrm{a}$ \\
Control (distilled water) & No record of \\
C.V. $=9.94 \%$ & mortality \\
\hline
\end{tabular}

Means ( \pm SEM) followed by the same letter in the column do not differ by the Scott-Knott test at $5 \%$ significance. $0.5 \mathrm{CR}=$ Half the recommended concentration; $\mathrm{CR}=$ recommended concentration; $2 \mathrm{CR}=$ Twice the recommended concentration. C.V. $=$ Coefficient of Variation. - = conidia concentration not sufficient to perform the bioassays.

In treatments where there was both reduction of and increased mortality, we suggest two alternative explanations: influence on time to fungal development or insect defense.

At first, we point that the treatments may have negatively influenced the metabolism of the fungus and its development, leading to the need for more time (in days) to colonize the insect; or the treatments may have affected the production or action of enzymes and toxins that act in colonization and death of the host, suggesting the need for a biochemical study to assess which enzymes and toxins may have been affected and how. This is based on Xiao et al. (2012), who emphasized that some gene families of $B$. bassiana developed mechanisms to increase production of proteases and chitinase, mediators of cell growth, regulators of extracellular acidification, degrading cuticular fatty acids and an important class of hydrophobins associated with the ability to adhere to the insect. All of these mechanisms related to fungus colonization may have suffered some negative influence by the peracetic acid at the rate $0.5 \mathrm{RC}$.

Also, in addition to the mechanisms of colonization, mechanisms of virulence may also have been affected. According to Von Döhren (2004), there are some factors related to fungal virulence that affects the immune system of the insect, including the production of a wide variety of compounds that act as immunosuppressant polyketide non-ribosomal, natural peptides, and toxins such as beauvericin and bassianolide. The latter also displays a 
high antibiotic activity, and its reduction may explain the non-confirmation of mortality by fungi in some cadavers; the action of the fungus may have weakened the immune system of the LMW and opportunistic bacteria may have caused the insect death.

The second hypothesis to explain reduced colonization and virulent is due to the immune system of the insect has had sufficient time to suppress fungal activity. Chouvenc et al. (2009) showed that the insects' immune system is quite efficient, verifying that in the hemolymph of termites, $24 \mathrm{~h}$ after exposure to the fungus Metarhizium anisopliae (Met), the amount of hemocytes had increased significantly. The authors noted the defense capacity of cell aggregation and melanization around the point of infection, in addition to the encapsulation and isolation of nodules, which, according to the authors, intensifies as the fungus takes longer to act.

To high action of the fungus, is it possible the aqueous extract may have enriched the culture medium providing a greater quantity of compounds to be assimilated by fungus and the fungus' rapid metabolism increased the production of extracellular proteases, and therefore, unlike that observed with peracetic acid, the infectious process is accelerated and increased the percentage of mortality (Rombach, 1989; Leite et al., 2003; Ito et al., 2007).

Comparing these hypotheses, it is possible to infer that the insecticidal activity of the fungus was influenced by the addition of the extracts to the medium. Some secondary compounds present in the extracts have insecticidal action, their residues may have remained with the fungus at the time of scraping and these compounds may have affected the immune system of the insect, leaving it weakened and assisting in the infectious processes of the fungus. The results obtained here suggest the need for a study characterizing how the enzymes and toxins are affected by the extracts and products.

Thus, all of the extracts and the Peroxitane at $0.5 \mathrm{RC}$ are compatible with $B$. bassiana Unioeste 4, although extracts had a low impact on the inoculum potential of the fungus. Also, the insecticidal activity of the fungus to LMW showed that the mortality rates caused by the fungus from culture media with aqueous and alcoholic extracts were not adversely affected but increased when fungus were produced on culture media with aqueous extract of guava. Peracetic acid in the $0.5 \mathrm{RC}$ had negatively influence on the fungus activity, demonstrating the negative action of the disinfectant on the insecticide potential of the fungus. As know, this negative effect here observed does not always mean that the same will occur in the field, but it shows a possibility for this to occur in poultry house (Alves et al., 1998a).

The results of this study demonstrate the possibility of the combined use of plant extracts and B. bassiana in poultry houses. It is important to allow for a period of 48 hours after inoculation of the fungus and treatment with the extracts; this time is required for spore germination and host invasion by the fungus. In aviaries, applications to control bacteria are usually performed preventively, i.e., before poultry installation, and as B. bassiana does not offer any risk, to the poultry, it can be applied before poultry installation, which favors the use of this combined control strategy of bacteria and $A$. diaperinus.

\section{Conclusions}

Peracetic acid affect all the fungus parameter while vegetal extracts had none negative effect on the fungus. Even so, all the extracts and Peroxitane at RC 0.5 are compatible with the fungus $B$. bassiana Unioeste 04, however only the extracts had a low impact on inoculum potential.

\section{Acknowledgements}

Ao CNPq e CAPES to financial support to development of this study.

\section{References}

ALVES, L.F.A., GASSEN, M.H., PINTO, F.G.S., NEVES, P.M.O.J. and ALVES, S.B., 2005. Ocorrência natural de Beauveria bassiana (Bals.) Vuilleman (Moniliales: Moniliaceae) sobre o cascudinho (Alphitobius diaperinus) (Panzer) (Coleoptera: Tenebrionidae), em aviários comerciais de Cascavel, PR. Neotropical Entomology, vol. 34, no. 3, pp. 507-510. http://dx.doi.org/10.1590/S1519$566 \times 2005000300021$

ALVES, S.B., MOINO JÚNIOR, A., ALMEIDA, J.E.M., 1998a. Produtos fitossanitários e entomopatógenos. In: S.B. ALVES, ed. Controle microbiano de insetos. 2nd ed. Piracicaba: Fealq, pp. 217-238.

ALVES, S.B., MOINO JÚNIOR, A., ALMEIDA, J.E.M., 1998 b. Técnicas de laboratório. In: S.B. ALVES, ed. Controle microbiano de insetos. 2nd ed. Piracicaba: Fealq, pp. 637-711.

BERMUDEZ, A.J. and STEWART-BROWN, B., 2003. Principles of disease prevention diagnosis and control: disease prevention and diagnosis. In: Y.M. SAIF, H.J. BARNES, A. FADLY, J.R. GLISSON, L.R. MCDOUGALD and D.E. SWAYNE. Disease of poultry. 11th ed. Iowa: Iowa State University Press, pp. 17-55.

BONEET, L.P., MULLER, G.M., WESSLING, C.R. and GAMELLO, F.P., 2012. Extrato etanólico de representantes de cinco famílias de plantas e óleo essencial da família Asteraceae sobre o fungo Colletotrichum gloeosporioides coletados de frutos de mamoeiro (Carica papaya L.). Revista Brasileira de Agroecologia, vol. 7, no. 3, pp. 116-125.

CHERNAKI-LEFFER, A.M., 2004. Dinâmica populacional, estimativa da resistência a inseticidas e alternativas de controle para o cascudinho Alphitobius diaperinus (Panzer, 1797) (Coleoptera: Tenebrionidae).Curitiba: Universidade Federal do Paraná, 123 p. Tese de Doutorado em Entomologia.

CHERNAKI-LEFFER, A.M., KUTTEL, J., MARTINS, L.M., PEDROSO, A.C., ASTOLFI-FERREIRA, C., FERREIRA, F. and FERREIRA, A.J.P., 2010. Vectorial competence of larvae and adults of Alphitobius diaperinus in the transmission of Salmonella enteritidis in poultry. Vector-Borne and Zoonotic Diseases, vol. 10 , no. 5, pp. 481-487.

CHERNAKI-LEFFER, A.M., SOSA-GOMEZ, D.R., ALMEIDA, L.M. and LOPES, I.O.N., 2011. Suscetibility of Alphitobius 
diaperinus to cypermethrin, dichlorvos and triflumuron in Southern Brazil. Revista Brasileira de Entomologia, vol. 55, no. 1, pp. 125-128. http://dx.doi.org/10.1590/S0085-56262011000100020.

CHOUVENC, T., SU, N.Y. and ROBERT, A., 2009. Cellular encapsulation in the eastern subterranean termite, Reticulitermes flavipes (Isoptera), against infection by the entomopathogenic fungus Metarhizium anisopliae. Journal of Invertebrate Pathology, vol. 101, no. 3, pp. 234-241. http://dx.doi.org/10.1016/j.jip.2009.05.008. PMid:19463828.

COCK, I.E., 2012. Antimicrobial activity of Syzygium australe and Syzygium luehmannii leaf methanolic extracts. Pharmacol Commun Res Letters, vol. 2, no. 2, pp. 71-77.

DE BONA, E.A.M., 2012. Comparação de métodos de avaliação e atividade antimicrobiana de extratos vegetais sorovares de Salmonella spp. de origem avícola. Cascavel: Universidade Estadual do Oeste do Paraná, 74 p. Dissertação de Mestrado em Conservação e Manejo de Recursos Naturais.

DESPINS, J.L. and AXTELL, R.C., 1995. Feeding behavior and growth of broiler chicks fed larvae of the darkling beetle, Alphitobius diaperinus. Poultry Science, vol. 74, no. 2, pp. 331-336. http://dx.doi.org/10.3382/ps.0740331.PMid:7724456.

DINIZ, D.N., MACEDO-COSTA, M.R., PEREIRA, M.V., PEREIRA, J.V. and HIGNO, J.S., 2010. In vitro antifungical effect os leaves and bark of Myciaria cauliflora Berg. Extract upon oral microorganisms. Revista de Odontologia da UNESP, vol. 39 , no. 3 , pp. 151-156.

FERREIRA, D.F., 2011. SISVAR: a computer statistical analysis system. Ciência e Agrotecnologia, vol. 35, no. 6, pp. 1039-1042.

FRUET, T.K., 2010. Avaliação da atividade microbiana de extratos vegetais frente a sorovares de Salmonella spp. de origem avícola. Cascavel: Universidade Estadual do Oeste do Paraná, 78 p. Monografia de Conclusão do Curso de Ciências Biológicas.

GÓRNIAK, S.L. and SPINOSA, H.S., 2007. Antimicrobianos na aviculture: usos e restrições. In: R.L. ANDREATTI-FILHO. Saúde Aviária e Doenças. São Paulo: Roca, pp. 35-40.

GREZZI, G., 2008 [viewed 06 September 2013]. Limpeza e desinfecção na avicultura [online]. Engormix. Available from: www.pt.engormix.com/MA-avicultura/saude/artigos/limpezadesinfeccao-avicultura-100/165-p0.htm

HAZELEGER, W.C., BOLDER, N.M., BEUMER, R.R. and JACOBS-REILTSMA, W.F., 2008. Darking beetles (Alphitobius diaperinus) and their larvae as potential vectors for the transfer of campylobacter jejuni and Salmonella enterica serovar Paratyphi $\mathrm{B}$ variant vava between successive broiler flocks. Applied and Environmental Microbiology, vol. 74, no. 22, pp. 6887-6891. http://dx.doi.org/10.1128/AEM.00451-08. PMid:18791034.

ITO, E.T., PEREIRA, G.V., MIYAGUI, D.T., PINOTTI, M.H.P. and NEVES, P.M.O.J., 2007. Production of extracellular proteases by a Brazilian strain of Beauveria bassiana reactivated on coffee berry borer Hypothenemus hampei. Brazilian Archives of Biology and Technology, vol. 50, no. 2, pp. 217-223. http:// dx.doi.org/10.1590/S1516-89132007000200006.

JAENISCH, F.R.F., KUCHIISHI, S.S. and COLDEBELLA, A., 2010. Atividade antibacteriana de desinfetantes para uso na produção orgânica de aves. Ciência Rural, vol. 40, no. 2, pp. 384-388. http://dx.doi.org/10.1590/S0103-84782010000200020.

LEITE, L.G., BATISTA-FILHO, A., ALMEIDA, J.E.M. and ALVES, S.B., 2003. Produção de fungos entomopatogênicos. Ribeirão Preto: Livroceres. 92 p.
LOGUERCIO, A.P., BATTISTIN, A., VARGAS, A.C., HENZEL, A. and WITT, N.M., 2005. Atividade antibacteriana de extrato hidro-alcoólico de folhas de Jambolão (Syzygium cumini (L. skells)). Revista Ciência Rural, vol. 35, no. 2, pp. 371-376. http:// dx.doi.org/10.1590/S0103-84782005000200019.

MACEDO-COSTA, M.R., DINIZ, D.N., CARVALHO, C.M., PEREIRA, M.S.V., PEREIRA, J.V. and HIGINO, J.S., 2009. Eficiência de extratos de Myciaria cauliflora (Mart.) O. Berg. (jabuticabeira) sobre bactérias orais. Revista Brasileira Farmacognosia, vol. 19, no. 2, pp. 565-571. http://dx.doi. org/10.1590/S0102-695X2009000400010.

MAMPRIM, A.P., ALVES, L.F.A., BONINI, A.K., FORMENTINI, M.A. and MARTINS, C.C., 2013. Efeito de defensivos agrícolas naturais e extratos vegetais sobre parâmetros biológicos de Metarhizium anisopliae (Metsch.) Sorok. Semina: Ciências Agrárias, vol. 34, no. 4, pp. 1451-1466.

MELLINGER, C.G., 2006. Caracterização estrutural e atividade biológica de carboidratos de Phyllanthus niruri (Quebra-pedra). Curitiba: Universidade Federal do Paraná, 139 p. Tese de Doutorado em Bioquímica.

MOINO-JUNIOR, A. and ALVES, S.B., 1998. Efeito de imidacloprid e fipronil sobre Beauveria bassiana (Bals.) Vuill., e Metarhizium anisopliae (Metsch.) Sorok., no comportamento de limpeza de Heterotermes tenuis (Hagen). Anais da Sociedade Entomológica do Brasil, vol. 30, no. 2, pp. 611-619. http://dx.doi.org/10.1590/ S0301-80591998000400014

OLIVEIRA, D.G.P., 2009. Proposta de um protocolo para avaliação da viabilidade de conídios de fungos entomopatogênicos e determinação da proteção ao calor conferida a Beauveria bassiana e Metarhizium anisopliae pela formulação em óleo emocionável. Piracicaba: Escola Superior de Agricultura Luiz de Queiroz, 89 p. Dissertação de Mestrado em Ciências.

OLIVEIRA, D.G.P., ALVES, L.F.A. and SOSA-GÓMEZ, D.R., 2014. Advances and perspectives of the use of the entomopathogenic fungi Beauveria bassiana and Metarhizium anisopliae for the control of arthropod pests in poultry production. Brazilian Journal Poultry Science, vol. 16, no. 1, pp. 1-12

O’CONNOR, J.P., 1987. Alphitobius diaperinus (Panzer) (Col. Tenebrionidae) damaging polystyrene insulation in Irish piggery. Entomologist's Monthly Magazine, vol. 123, no. 50, pp. 1472-1475.

OSTROSKY, E.A., MIZUMOTO, M.K., LIMA, M.E.L., KANEKO, T.M., NISHIKAWA, S.O. and FREITAS, B.R., 2008. Métodos para avaliação da atividade antimicrobiana e determinação da concentração mínima inibitória (CMI) de plantas medicinais. Revista Brasileira de Farmacognosia, vol. 12, no. 2, pp. 301-307. http://dx.doi.org/10.1590/S0102-695X2008000200026.

PADILHA, T., 2004 [viewed 12 Febuary 2013]. Resistência antimicrobiana x produção animal: uma discussão internacional [online]. EMBRAPA. Available from: http://www.embrapa.br/ imprensa/artigos/2000/artigo.2004-12-07.2546062632/

RODRIGUES, E., DUARTE-ALMEIDA, J.M. and PIRES, J.M., 2010. Perfil farmacológico e fitoquímico de plantas indicadas pelos caboclos do parque nacional do Jaú (AM) como potenciais analgésicas. Revista Brasileira Farmacognosia, vol. 20, no. 6, pp. 981-991. http://dx.doi.org/10.1590/S0102-695X2010005000008.

ROHDE, C., ALVES, L.F.A., NEVES, P.M.O.J., ALVES, S.B., SILVA, E.R.L. and ALMEIDA, J.E.M., 2006. Seleção de Isolados de Beauveria bassiana (Bals.) Vuill. e Metarhizium anisopliae (Metsch.) Sorok. contra o Cascudinho Alphitobius diaperinus (Panzer) (Coleoptera: Tenebrionidae). Neotropical Entomology, 
vol. 35, no. 2, pp. 231-240. http://dx.doi.org/10.1590/S1519566X2006000200012. PMid:17348135.

ROMBACH, M.C., 1989. Production of Beauveria bassiana (Deuteromycotina Hyphomycetes) Sympoduloconidia in submerged culture. Entomophaga, vol. 34, no. 1, pp. 45-52. http://dx.doi. org/10.1007/BF02372586.

ROSSI-ZALAF, L.S., ALVES, S.B., LOPES, R.B., SILVERIRA NETO, S. and TANZINI, M.R., 2008. Interação de microrganismos com outros agentes de controle de pragas e doenças. In: S.B. ALVES, R.B. LOPES, eds. Controle microbiano de pragas na América Latina: avanços e desafios. Piracicaba: FEALQ, pp. 279-302.

RUTALA, W., 1997. Disinfection, sterilization and waste disposal. In: R. WENZEL, ed. Prevention and control of nosocomial infections. 3rd ed. Williams and Wilkins, $27 \mathrm{p}$.

SCOPARO, C.T., 2011. Análise dos polissacarídeos presentes em Camella sinensis e desenvolvimento de cromatografia líquida bidimensional abrangente para compostos de baixa massa molecular. Curitiba: Universidade Federal do Paraná, 107 p. Dissertação de Mestrado em Bioquímica.

SILVA, R.Z., NEVES, P.M.O.J. and SANTORO, P.H., 2005. Técnicas e parâmetros utilizados nos estudos de compatibilidade entre fungos entomopatogênicos e produtos fitossanitários. Semina: Ciências Agrárias., vol. 26, no. 3, pp. 305-312.

UNIÃO BRASILEIRA DE AVICULTURA E DE EXPORTADORES DE FRANGO - UBABEF, 2013 [viewed 10 August 2013]. Relatório anual [online]. 109 p. Available from: http://www.ubabef.com. br/files/publicacoes/732e67e684103d e4a2117dda9ddd280a.pdf

VARGAS-ALVAREZ, D., SOTO-HERNÁNDEZ, M., GONZÁLEZHERNÁNDEZ, V.A., ENGLEMAN, E.M. and MARTÍNEZGARZA, A., 2006. Cinética de acumulación y distribución de flavonoides en guayaba (Psidium guajava L.). Agrociencia, vol. 40, pp. 109-115.

VON DOHREN, H., 2004. Biochemistry and general geneticis of nonribosomal peptide synthetase in fungi. Advances in Biochemical Engineering/Biotechnology, vol. 88, pp. 217-264. http://dx.doi. org/10.1007/b99262. PMid:15719557.

XIAO, G., YING, S.H., ZHENG, P., WANG, Z.L., ZHANG, S., XIE, X.Q., SHANG, Y., LEGER, R.J.S.T., ZHAO, G.P., WANG, C. and FENG, M.G., 2012. Genomic perspectives on the evolution of fungal entomopathogenicity in Beauveria bassiana. Scientific Reports, vol. 2, no. 1, pp. 1-10. PMid:22761991. 